\title{
Aplikasi Dimmer Switch pada Rak Kultur Sebagai Pengatur Kebutuhan Intesitas Cahaya Optimum Bagi Tanaman In Vitro
}

\author{
Fifit Yuniardi ${ }^{1}$ \\ ${ }^{1}$ Politeknik Negeri Lampung,Bandar Lampung,35142,E-mail : Putragemini86@gmail.com \\ Submisi : 14 Agustus 2019; Penerimaan : 12 September 2019
}

\begin{abstract}
ABSTRAK
Kultur jaringan tanaman adalah salah satu cara menumbuhkan organ tanaman dalam suatu wadah/botol yang berisi media dalam keadaan steril. Tujuannya untuk mendapatkan tanaman dalam jumlah besar dalam waktu yang singkat. Faktor-faktor lingkungan yang dapat mempengaruhi pertumbuhan dan perkembangan tumbuhan dalam proses pertumbuhan dalam kultur in vitro, antara lain adalah cahaya. Kualitas, intensitas, dan lamanya radiasi yang mengenai tumbuhan mempunyai pengaruh yang besar terhadap berbagai proses fisiologi tumbuhan.

Untuk mendapatkan hasil pertumbuhan yang optimal metode cahaya sangat dibutuhkann, namun yang perlu diperhatikan adalah kebutuhan cahaya dalam proses kultur Jaringan berbeda-beda dimana dalam proses inisiasi pembelahan sel pada eksplan dan pertumbuhan jaringan kalus terkadang mengalami hambatan dengan adanya cahaya sedangkan dalam pertumbuhan pemanjangan bagian tanaman dan pengakaran kebutuhan cahaya lebih meningkat. Intensitas cahaya yang optimum untuk tanaman pada tahap kultur inisiasi 1-1.000 lux, tahap multiplikasi 1.000-10.000 lux, tahap pengakaran 10.000 - 30.000 lux dan tahap aklimatisasi sebesar 30.000 lux. Adanya aplikasi pada rak kultur diharapkan dapat mengatur cahaya sesuai kebutuhan tanaman dalam kegiatan kultur in vitro.
\end{abstract}

Kata kunci : kultur jaringan; cahaya; aplikasi dimmer switch.

\section{PENDAHULUAN}

\section{Latar Belakang}

Kultur jaringan Tanaman adalah salah satu cara menumbuhkan organ tanaman dalam suatu wadah/botol yang berisi media dalam keadaan steril. Tujuannya untuk mendapatkan tanaman dalam jumlah besar dalam waktu yang singkat. Selain itu diperoleh tanaman yang bebas virus, membantu pemulian tanaman untuk mempercepat pencapaian tujuan penelitian pada tanaman yang biasa diperbanyak secara vegetatif.

Kultur jaringan memiliki pengertian yang luas mengenai kultur in vitro berbagai bagian tanaman pada kondisi nutrisi dan lingkungan yang aseptic dan terkendali. Dibandingkan dengan perbanyakan tanaman secara konvensional perbanyakan tanaman secara kultur jaringan banyak mempunyai kelebihan seperti perbanyakan secara kultur jaringan menawarkan peluang besar untuk menghasilkan jumlah bibit tanaman yang banyak dalam relative singkat, tidak membutuhkan tempat yang luas, tidak tergantung oleh musim, bibit yang dihasilkan lebih sehat dan dapat memungkinkan dilakukannya manipulasi genetik.

Faktor-faktor lingkungan yang dapat mempengaruhi pertumbuhan dan perkembangan tumbuhan dalam proses pertumbuhan dalam kultur in vitro, antara lain adalah cahaya. Kualitas, intensitas, dan lamanya radiasi yang mengenai tumbuhan mempunyai pengaruh yang 
besar terhadap berbagai proses fisiologi tumbuhan.

Cahaya mempengaruhi
pembentukan klorofil, fotosintesis,
fototropisme, dan fotoperiodisme. Efek cahaya meningkatkan kerja enzim untuk memproduksi zat metabolik untuk pembentukan klorofil. Sedangkan, pada proses fotosintesis, intensitas cahaya mempengaruhi laju fotosintesis saat berlangsung reaksi terang. Jadi cahaya secara tidak langsung mengendalikan pertumbuhan dan perkembangan tanaman, karena hasil fotosintesis berupa karbohidrat digunakan untuk pembentukan organ-organ tumbuhan.

Seperti halnya

pertumbuhan tanaman dalam kondisi invivo, kuantitas dan kualitas cahaya, yaitu intensitas, lama penyinaran dan panjang gelombang cahaya mempengaruhi pertumbuhan eksplan dalam kultur invitro. Pertumbuhan organ atau jaringan tanaman dalam kultur in-vitro umumnya tidak dihambat oleh cahaya, namun pertumbuhan kalus umumnya dihambat oleh cahaya.

Dalam teknik kultur jaringan tanaman (in vitro) cahaya dinyatakan dengan dimensi lama penyinaran, intensitas dan kualitasnya. Prof. Murashige menyarankan untuk mengasumsikan kebutuhan lama penyinaran dalam kultur jaringan tanaman merupakan pencerminan dari kebutuhan periodisitas tanaman yang bersangkutan dilapangan. Kualitas cahaya mempengaruhi arah diferensiasi jaringan. Energy radiasi dekat dengan spectrum ultraviolet dan biru merupakan kualitas cahaya yang paling efektif untuk merangsang pertumbuhan tunas, sedangkan pembentukan akar dirangsang oleh cahaya merah dan sedikit cahaya biru. Untuk itu tahap inisiasi dan multiplikasi tunas digunakan pencahayaan dengan lampu fluorescent atau TL (Yusnita, 2004).
Intensitas cahaya yang optimum untuk tanaman pada tahap kultur inisiasi 1-1.000 lux, tahap multiplikasi 1.00010.000 lux, tahap pengakaran 10.000 30.000 lux dan tahap aklimatisasi sebesar 30.000 lux. Kultur yang kurang cahaya biasanya menunjukan gejala etiolasi dan vitrifikasi. Etiolasi dengan ciri panjangnya ruas tanaman yang terbentuk, vitrifikasi ditandai dengan sukulensi, batang bening, dan lemas, karena banyak mengandung air (Sandra, 2018).

Permasalahan yang timbul adalah cukup tidaknya lampu flourescent (TL) yang menyala sesuai dengan kebutuhan tanaman dalam proses pertumbuhannya. Dimana proses pertumbuhan tanaman in vitro dimulai dari inisiasi, pertumbuhan kalus, pertumbuhan tunas, multiplikasi serta pengakaran membutuhkan itensitas cahaya yang berbeda-beda. Oleh karena itu perlu adanya cara untuk mengecek tingkat itensitas cahaya dan bagaimana mengatur agar itensitas cahaya yang diterima oleh tanaman sesuai dengan kebutuhan tanaman dalam kegiatan in vitro.

Untuk mendapatkan hasil pertumbuhan yang optimal tetap cahaya sangat dibutuhkann namun yang perlu diperhatikan adalah kebutuhan cahaya dalam proses kultur in vitro berbedabeda dimana dalam proses inisiasi pembelahan sel pada eksplan dan pertumbuhan jaringan kalus terkadang mengalami hambatan dengan adanya cahaya sedangkan dalam pertumbuhan pemanjangan bagian tanaman dan pengakaran kebutuhan cahaya lebih meningkat. Oleh Karena itu perlu adanya terobosan dalam pembuatan alat yang dapat mengatur cahaya sesuai kebutuhan tanaman dalam kegiatan kultur in vitro.

Berdasarkan permasalahan yang telah disebutkan, penulis selaku 
tenaga pendidik di lingkungan Politeknik Negeri Lampung berinisiatif untuk merancang sebuah penelitian berupa pembuatan rak kultur yang diberikan alat dimmer switch yang digunakan untuk meletakan tanaman dalam ruang inkubasi.

\section{Tujuan Penelitian}

Tujuan Penelitian Aplikasi Dimmer Switch Pada Rak Kultur Sebagai Pengatur Kebutuhan Intesitas Cahaya Optimum Bagi Tanaman In Vitro adalah untuk meningkatkan dan mengoptimalkan pelayanan praktikum dengan Inovasi pembuatan alat tepat guna baru yang mendukung dalam kegiatan praktikum kultur Jaringan, Serta Mata kuliah lain yang terkait dengan pemakaiana laboratorium kultur jaringan.

\section{METODE PENELITIAN}

\section{Waktu dan Tempat Penelitian}

Penelitian akan dilakukan di laboratorium kultur jaringan Politeknik Negeri Lampung. Penelitian dilakukan mulai bulan April sampai September 2019.

\section{Bahan dan alat}

Bahan yang digunakan dalam penelitian ini adalah batang alumunium $15 \mathrm{~mm}$, tripleks melamin $9 \mathrm{~mm}$, baut, lem kayu, lampu TL 40 watt full body, kabel nym $0,75 \mathrm{~mm}$, saklar, steker, stop kontak. Sedangkan alat yang digunakan dalam pelaksanaan penelitian ini antara lain lux meter, bor listrik, Tool kit, Pensil 2B, multi tester, Soldier, dimmer switch.

\section{Rancangan Penelitian}

Penelitian ini dilakukan dengan beberapa tahapan yaitu dengan persiapan pembuatan dan inventarisasi alat dan bahan yang di butuhkan, lalu merancang bentuk dan sistem kerja peralatan, kemudian pembuatan rak kultur dan perakitan lampu serta peralatan yang mendukung lalu uji coba alat yang dibuat dan terakhir pengamatan hasil dari peralatan.

\section{Pelaksanaan Penelitian:}

1. Persiapan Mengifentaris dan mengumpulkan semua peralatan dan bahan yang akan digunakan dalam penelitian, membuat rak kultur yang akan digunakan untuk meletakan botol-botol kultur yang berisi tanaman, menyiapkan tanaman dalam botol kultur dari fase kalus, propagul/protocorm dan platet.

2. Pembuatan rak kultur

a. Mengukur kebutuhan bahan alumunium dan tripleks melamin yang dibutuhkan untuk membuat rak kultur 4 tingkat.

b. Merangkai bagian bagian yang telah diukur hingga terbentuk rak kultur.

c. Pemasangan instalansi listrik dan alat dimmer switch pada rak kultur dan diletakan di ruang inkubasi.

3. Uji coba Alat.

Setelah kegiatan perakitan rak kultur yang telah dipasang instalansi listrik, lampu TL dan dimmer switch selesai, Alat tersebut siap dilakukan uji coba alat di laboratorium kultur jaringan Politeknik Negeri Lampung. Adapun uji coba yang dilaksanakan adalah :

a. Menghidupkan lampu TL yang dirakit pada rak kultur pada ruang inkubasi

b. Mengukur kerapatan lux dengan menggunakan lux meter pada rak kultur dengan mengarahkan sensor keruangan inkubasi.

c. Mengatur kerapatan lux dengan dimmer switch sesuai dengan yang diinginkan. Bila terlalu tinggi kerapatan lux dapat diturunkan dengan mengecilkan dimmer switch dan bila kerapatan lux 
kurang dapat dilakukan dengan penambahan lampu TL.

d. Meletakan botol kultur yang berisi eksplan atau platet sesuai dengan kebutuhan tanaman akan kerapatan lux pada rak kultur.

e. Mengamati akan pertumbuhan tanaman dan menganalisis kesesuaian pertumbuhan eksplan atau platet dengan hasil yang diharapkan.

4. Pengamatan

Pengamatan meliputi:

a. Kesesuaian kerapatan lux sesuai yang diharapkan dengan lux meter

b. Melihat pertumbuhan eksplan ataupun plantet pada botol-botol kultur.

\section{HASIL DAN PEMBAHASAN}

Hasil pengamatan pertumbuhan tunas menunjukan perbedaan yang nyata, dimana pertumbuhan dengan lux yang tinggi menghasilkan pertumbuhan yang lebih baik dibandingkan dengan lux yang remdah. Namun dari hasil pengukuran yang didapatkan, tidak semua titik pengukuran memenuhi batas minimumdan maksimum pencahayaan. Hal tersebut di karenakan adanya beberapa titik ruangan rak yang jauh dari sumber cahaya dari lampu. Faktor lain yang dapat menyebabkan pencahayaan tersebut kurang terang adalah adanya kemungkinan tertutup / terhalang oleh benda-benda sehingga menghalangi cahaya. Pada beberapa titik pengukuran menunjukkan hasil pengukuran yang cukup tinggi yaitu mencapai 1246 dan 1519 lux. Untuk tahap inisiasi pada tanaman pisang dari hasil pengamatan dengan lux mencapai 973 lux tunas mulai muncul dari proses inisiasi tersebut sedangkan denga tingkat pencahayaan 030 lux terjadi penghambatan dalam proses inisiasi pisang tersebut.
Tinggi cahaya yang diperlukan pada proses inisiasi sekitar 1- 1.000 lux, dimana dalam proses inisiasi cahaya dibutuhkan dalam proses fotomorfogenesis. Hal ini berbeda dengan perkecambahan yang terjadi dalam prosesnya (generative), dimana kecambah akan lebih cepat tumbuh pada keadaan yang pencahayaannya kurang namun dalam proses kultur jaringan pencahayaan dibutuhkan untuk Perkembangan struktur tumbuhan. Jenis tanaman yang berbeda memungkinkan terjadi perbedaan kebutuhan tinggi cahaya yang berbeda-beda pula. Akan tetapi pemberian cahaya yang sangat terlalu tinggi dapat menghambat dalam pemanjangan tunas akibat terhambatnya hormone auksin dalam proses pertumbuhan tunas.

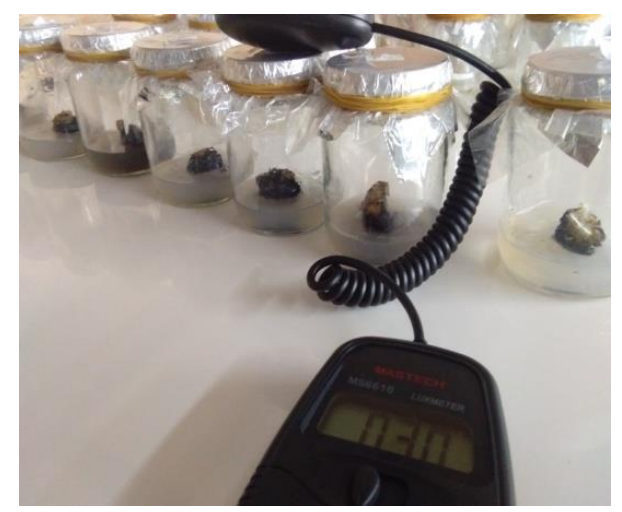

a

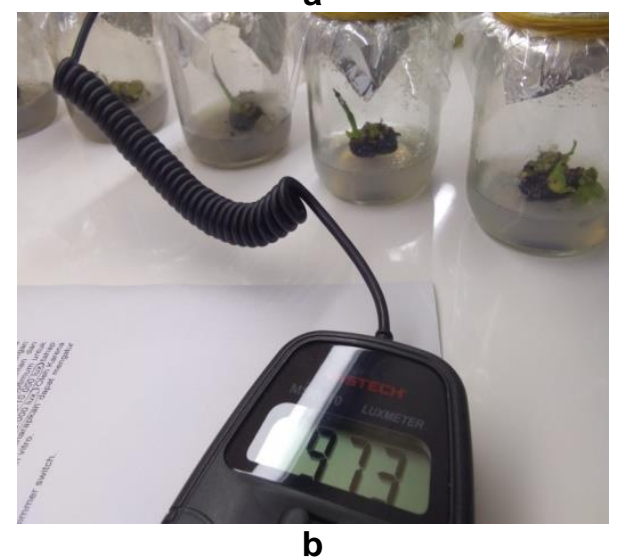

Gambar 1. a) tingkat pencahayaan 30 lux, b) tingkat pencahayaan 973 lux 
Dalam gambar 2 tingkat kebutuhan cahaya dalam proses inisiasi tunas aksilar aglonema juga menunjukan lux yang lebih tinggi menghasilkan kecepatan pertumbuhan tunas.
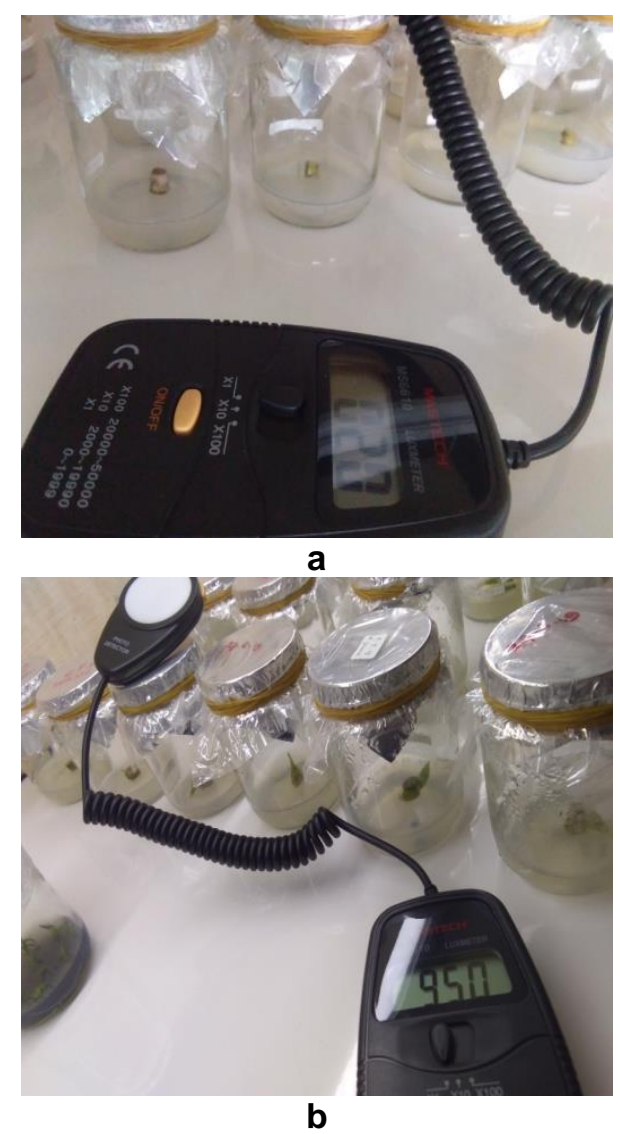

Gambar 2. Tanaman Aglonema dengan a) tingkat pencahayaan 20 lux, b) tingkat pencahayaan 950 lux

Dengan itensitas cahaya yang kurang diterima oleh tanaman akan menyebabkab kerusakan auksin yang berperan dalam kegiatan pemanjangan tunas dari eksplan tanaman. Hasil pengamatan juga menunjukan tanaman yang kurang mendapatkan cahaya sebagian besar plantet mengalami kematian.

Dalam kegiatan kultur jaringan terdapat tahapan-tahapan yang harus dilakukan sebelum eksplan menjadi tanaman yang siap untuk di tanam di lingkungan luar. tahap atau proses kultur jaringan berbeda-beda inilah maka kebutuhan tanaman terhadap cahaya juga akan berbeda. Walaupun dalam kultur jaringan zat pengatur tumbuh sangat mempengaruhi pertumbuhan namun dengan diimbangi dengan pencahayaan yang optimum maka proses perbanyakan tanaman (tunas) akan lebih menghasilkan jumlah tunas yang lebih banyak karena cahaya dapat menghambat dominasi pertumbuhan apikal.

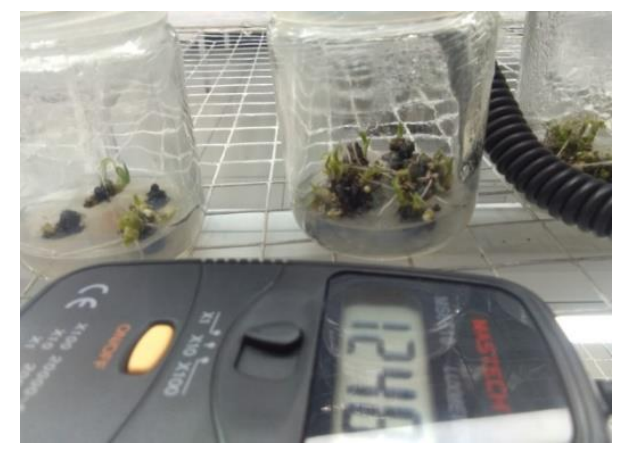

a

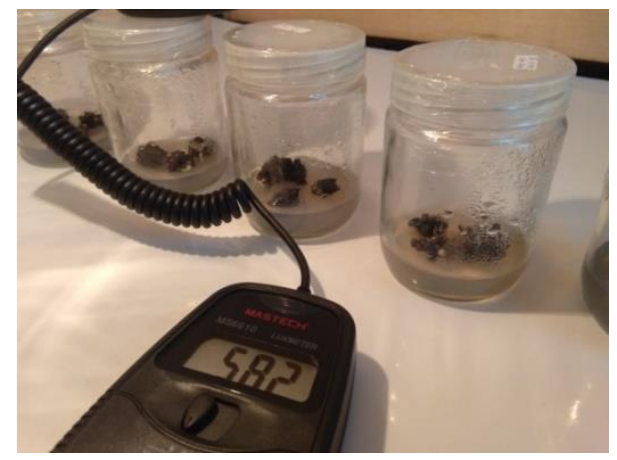

b

Gambar 3. Tahap multifikasi tanaman pisang pada a) tingkat pencahayaan 1248 lux, b) tingkat pencahayaan 582 lux

Dalam proses perbanyakan atau tahap multiplikasi dari kegiatan yang telah dilaksanakan menunjukan kebutuhan cahaya semakin tinggi karena efek cahaya dapat meningkatkan kerja enzim untuk memproduksi zat metabolik untuk pembentukan klorofil. Multiplikasi adalah kegiatan eksplan dalam memperbanyak jumlah bagian tanaman, untuk kultur in vitro sendiri kegiatan 
multiplikasi sebagian besar ditujukan untuk perbanyakan tunas.

\section{PENUTUP}

\section{Kesimpulan}

Berdasarkan hasil pembahasan maka dapat disimpulkan tingkat kebutuhan cahaya yang disebut lux sangat perlu diperhatikan dalam kegiatan kultur in vitro. Hal ini dapat dilihat dari pembahasan diatas dimana tingkat kebutuhan cahaya pada saat inisiasi dan multiplikasi sangat jelas. Dari uraian tersebut tahapan inisiasi membutuhkan tingkat cahaya rendah dan pada tahap multiplikasi kebutuhan cahaya akan lebih meningkat, disamping tanaman akan mengalami kematian bila tidak mendapatkan cahaya yang sesuai engan kebutuhannya. Hal ini akan bertolak belakang bila saja perbanyakan tanaman dilaksanakan secara organogenesis tidak langsung atau melewati tahap pengkalusan dimana tanaman lebih membutuhkan fase gelap dibandingkan fase terang.

\section{Saran}

Perlu dilakukan penelitian lebih lanjut mengenai kebutuhan cahaya terhadap tanaman in vitro. Karena kegiatan yang telah dilaksanakan ini masih banyak sekali kekurangan dimana tidak adanya pengujian terhadap lebih banyak tanaman sebagai sample. Keterbatasan waktu dan tempat juga mempengaruhi kurangnya data pengamatan untuk menentapkan kebutuhan cahaya. Diharapkan akan ada masa dimana pengoptimalisasi cahaya dapat membantu para peneliti dalam pengambilan keputusan dan pihak pengembang dapat mengurangi out put dalam membiayai produksi tanaman secara kultur in vitro.

\section{DAFTAR PUSTAKA}

Sandra, E. 2018 . Buku Pelatihan Kultur Jaringan Esha Flora. Esha Flora . Bogor. 105 hal.

Sulistiani, E dkk. 2018. Produksi Bibit Tanaman Dengan Menggunakan Teknik Kultur jaringan. Seameo Biotrop. Bogor

Yusnita. 2004. Kultur Jaringan: Cara Memperbanyak Tanaman Secara Efisien. Agromedia Pustaka. Tanggerang. 105 hal.

Zulkarnain. 2009. Kultur Jaringan Tanaman: Solusi Perbanyakan Tanaman Budidaya. Bumi Aksara. Jakarta. 250 hal. 